\title{
Water Relations and Abscisic Acid in Pot-grown Strawberry Plants under Limited Irrigation
}

\author{
Nauja Lisa Jensen ${ }^{1,2}$, Christian R. Jensen, and Fulai Liu \\ Department of Agriculture and Ecology, Faculty of Life Sciences, University of Copenhagen, \\ Hoejbakkegaard Allé 13, DK-2630 Taastrup, Denmark \\ Karen K. Petersen \\ Department of Horticulture, Faculty of Agricultural Sciences, Aarhus University, Kirstinebjergvej 10, \\ DK-5792 Aarslev, Denmark
}

\begin{abstract}
Additional INDEX words. Fragaria $\times$ ananassa, ABA, partial root zone drying, deficit irrigation, leaf, crown, potential
Abstract. We investigated the effect of full irrigation (FI), deficit irrigation (DI), partial root zone drying (PRD), and nonirrigation (NI) on soil and plant-water relations, leaf stomatal conductance $\left(g_{\mathrm{s}}\right)$, and abscisic acid (ABA) concentration in the xylem sap ([ABA $]_{x y l e m}$ ) of pot-grown strawberry plants (Fragaria $\times$ ananassa $\mathrm{cv}$. Honeoye) in a greenhouse experiment. The DI and PRD treatments, irrigated with $70 \%$ of the volume of FI, reduced soil water content $(\theta)$, whereas crown water potential $\left(\psi_{\text {crown }}\right)$, leaf water potential $\left(\psi_{\text {leaf }}\right)$, and $g_{\text {s }}$ were only significantly reduced from 11 to 15 days after initiation of irrigation treatments. Although $[\mathrm{ABA}]_{\mathrm{xylem}}$ was not significantly affected by the DI and PRD treatments, the NI plants increased [ABA $]_{x y l e m}$, which coincided with decreased $\psi_{\text {crown }}, \psi_{\text {leaf }}$, and $g_{\mathrm{s}} 3$ to 4 days after withholding irrigation. When $\psi_{\text {crown }}$ dropped below a critical value of $-0.4 \mathrm{MPa}$, [ABA] $]_{\text {yylem }}$ was linearly correlated with $\psi_{\text {crown }}$. The $g_{\mathrm{s}}$ tended to decrease as a function of $[\mathrm{ABA}]_{\mathrm{xylem}}$, but $g_{\mathrm{s}}$ was also affected by the water vapor pressure deficit (VPD) of the air. It is concluded that we did not observe a significant difference between strawberry plants grown in PRD and DI because $\psi_{\text {crown }}$ had to be below -0.4 MPa and soil water potential $\left(\psi_{\text {soil }}\right)$ had to be below $-0.25 \mathrm{MPa}$ before $[\mathrm{ABA}]_{\mathrm{xylem}}$ increased, these values were only reached toward the end of the experimental period (11-15 days after initiation of irrigation treatments).
\end{abstract}

During the last decade, a novel irrigation strategy, partial root zone drying (PRD), has been developed for grape (Vitis vinifera) production (Dry and Loveys, 1999). The PRD irrigation technique was designed to trigger the abscisic acid (ABA)-based root-to-shoot chemical signaling system, inducing partial stomatal closure and modifying growth by reducing excessive vegetative growth and stimulating root growth and thereby increasing water use efficiency (Stoll et al., 2000). It is believed that in PRD plants, the ABA signal is mainly generated by the drying roots (Liu et al., 2008). The PRD approach is to withhold irrigation from a part of the plant root zone while the remaining part is kept well watered. PRD irrigation has been tested in a number of crops such as potato (Solanum tuberosum) (Shahnazari et al., 2007), hot pepper (Capsicum annum) (Guang-Cheng et al., 2008), and strawberry (Liu et al., 2007). In most cases, PRD irrigation has shown the potential to increase irrigation water use efficiency and to maintain yield relative to deficit irrigation (Davies and Hartung, 2004).

Strawberry is a shallow-rooted crop and therefore it is very sensitive to soil water deficits. Studies have shown that drought stress during flowering and fruit development significantly reduced berry size and yield (Hoppula and Salo, 2007; Liu et al., 2007). In fully irrigated plants, the plant water status is generally maintained between irrigations by replacing water on a daily basis according to the actual evaporative demand. However, when applying deficit irrigation (DI), irrigating with

Received for publication 19 May 2009. Accepted for publication 28 Sept. 2009. We thank The Danish Food Industry Agency of The Danish Ministry of Food, Agriculture, and Fisheries for financial support of this experiment.

${ }^{1}$ Current address: Department of Horticulture, Faculty of Agricultural Sciences, Aarhus University, Kirstinebjergvej 10, DK-5792 Aarslev, Denmark.

${ }^{2}$ Corresponding author.E-mail: NaujaLisa.Jensen@agrsci.dk. an amount lower than the full plant water requirement, a significant reduction in berry yield occurred at even moderate decreases in soil water potentials (Liu et al., 2007).

To optimize irrigation strategies for strawberries, it is important to know how different irrigation strategies influence physiological reactions (i.e., plant-water relations), stomatal conductance $\left(g_{\mathrm{s}}\right)$, and chemical signaling. Earlier studies have shown that strawberry is able to adjust osmotically to soil drying (Renquist et al., 1982; Save et al., 1993) and physiological parameters such as photosynthesis and transpiration do not decrease until the leaf water potential reaches $-1.0 \mathrm{MPa}$ (Sruamsiri and Lenz, 1986). To date, no published work has been reported on chemical signaling in xylem sap of Fragaria xananassa during soil drying, DI, or PRD.

PRD irrigation is based on the hypothesis that PRD plants perform better than DI plants when the same amount of water is applied (Davies and Hartung, 2004). This hypothesis is in contrast to findings by Liu et al. (2007), where PRD-grown strawberry plants showed no advantage compared with DI in terms of water use efficiency, $g_{\mathrm{s}}$, and $\psi_{\text {leaf }}$. In the present study, strawberry plants were subjected to full irrigation (FI), DI, $\mathrm{PRD}$, and nonirrigation (NI) treatments during the late vegetative stage of growth in an attempt to understand the physiological aspects of why PRD strawberry plants do not perform better than DI strawberry plants. The objective was to alter soil water dynamics and to investigate the irrigation effects on plantwater relations and $[\mathrm{ABA}]_{\mathrm{xylem}}$.

\section{Materials and Methods}

Experimental SET-UP. Fragaria Xananassa 'Honeoye' plantlets (strawberry frigo plants/A+) were planted in pots 
$15 \mathrm{~cm}$ in diameter and $25 \mathrm{~cm}$ deep on $27 \mathrm{Apr}$. 2007. The PRD pots were divided into two compartments by a plastic wall in the middle of the pot and roots of the strawberry plants were split evenly across the two soil compartments. Plants were randomly selected and placed into four blocks. The plants were grown under controlled conditions in a greenhouse with a 14-h photoperiod and temperature set points of $20 / 12{ }^{\circ} \mathrm{C}$ day/night. The actual day temperature varied between 20 and $35^{\circ} \mathrm{C}$ and the photosynthetic active radiation $(P A R)$ was $>600 \mu \mathrm{mol} \cdot \mathrm{m}^{-2} \cdot \mathrm{s}^{-1}$. The volumetric soil water content of all plants was maintained about pot holding capacity until the irrigation treatments started (13 June).

SoIL PhySICAL PROPERTIES. The soil originated from deep Weichselian moraine deposits at Foulum, Denmark, and contained $33 \%$ coarse sand $(0.2-2.0 \mathrm{~mm}), 43 \%$ fine sand $(0.02-0.2 \mathrm{~mm})$, $11 \%$ silt $(0.002-0.02 \mathrm{~mm}), 11 \%$ clay $(<0.002 \mathrm{~mm})$, and $2 \%$ organic matter. The soil was a loamy sand with a soil bulk density of $1.40 \mathrm{~g} \cdot \mathrm{cm}^{-3}$. The retention curve for the soil was determined by the pressure plate technique (Madsen et al., 1986) and the soil water matric potential $\left(\psi_{\text {soil }}\right)$ was described as $-10.8 \times \exp (-0.34 \times \theta)$.

IRRIGATION TREATMENT. The experiment was a complete randomized block design with four irrigation treatments: FI, DI, PRD, and NI. The FI plants were fully irrigated each day in the late afternoon according to weight loss of each pot, and $\theta$ was maintained at pot holding capacity ( $\theta$ about $25 \%)$. The volume of the daily irrigation in the FI treatment was calculated per pot as the total fresh weight of the whole pot at $100 \%$ of pot holding capacity ( FW $=7000 \mathrm{~g})$ - the actual fresh weight of the whole pot just before irrigation $\left(\mathrm{FW}_{\text {actual }}\right)$. The DI and PRD plants received $70 \%$ of the average water volume of the FI plants at each irrigation event during the treatment period. In the FI and DI treatments, irrigation was applied to the whole root system, whereas in the PRD plants, irrigation was only applied to one soil compartment at a time. When the dry side reached a $\theta$ below $10 \%$, the irrigation was switched from the right (PRD-R) to the left side (PRD-L) of the pot. The NI treatment was not irrigated during the treatment period.

SoIL WATER CONTENT. The volumetric soil water content of four plants per treatment was measured each morning by time domain reflectometer (TDR) probes (TRASE; Soil Moisture Equipment, Santa Barbara, CA) to ensure that pot holding capacity was maintained in the FI treatment and to follow the rate of drying in the other treatments (Fig. 1A). The 20-cm TDR probe was inserted in the center of each soil compartment of the PRD treatment to measure $\theta$ of PRD-R and PRD-L. The volumetric soil water content of FI, DI, and NI was measured in the same way and was determined by an average of the two values. The fraction of transpirable soil water (FTSW) was calculated from Eq. 1, where PW is the weight of the whole pot at permanent wilting $(\mathrm{PW}=6080 \mathrm{~g})$.

$$
\mathrm{FTSW}=\left(\mathrm{FW}_{\text {actual }}-\mathrm{PW}\right) /(\mathrm{FW}-\mathrm{PW}) \times 100
$$

$\boldsymbol{G}_{\mathrm{s}}$. Stomatal conductance of four plants per treatment was measured daily by a portable photosynthesis system (LI-6200; LI-COR, Lincoln, NE). Measurements occurred on $3 \mathrm{~cm}^{2}$ of the second fully expanded upper canopy leaf from 1100 to $1300 \mathrm{HR}$ under ambient light conditions. The ambient $\mathrm{CO}_{2}$ concentration was about $380 \mu \mathrm{L} \cdot \mathrm{L}^{-1}$.

Plant-water relations. Midday leaf water potential and crown water potential were measured $0,2,4,5,6,7,9,11,13$, and $15 \mathrm{~d}$ after start of treatments. Measurements of $\psi_{\text {leaf }}$ were carried out using a pressure chamber (Soil Moisture Equipment, Santa Barbara, CA) from 1100 to 1300 HR on the same leaves used for measurements of $g_{\mathrm{s}}$. After taking $\psi_{\text {leaf }}$ measurements, each leaf was divided into two parts, two-thirds of the leaf was immediately wrapped in aluminum foil, frozen in liquid nitrogen, and transferred to a $-80{ }^{\circ} \mathrm{C}$ freezer for subsequent $\psi_{\mathrm{s}}$ determination. The remaining one-third of the leaf was used for determination of relative water content (RWC). Leaf relative water content was measured following Barrs and Weatherley (1962).

To determine the $\psi_{\mathrm{s}}$, the frozen leaf samples were allowed to thaw for about $20 \mathrm{~min}$ before being pressed. The $\psi_{\mathrm{s}}$ of the leaf sap was measured by a dew point microvoltmeter (HR33T; Wescor, Logan, UT) and a sample chamber (C52; Wescor $)$. The $\psi_{\mathrm{s}}$ at full hydration $\left(\psi_{\mathrm{s} 100}\right)$ was calculated as $\psi_{\mathrm{s}} \times$ RWC. After determination of $\psi_{\text {leaf }}$ and $\psi_{\mathrm{s}}$, the turgor pressure $\left(\psi_{\mathrm{p}}\right)$ was calculated as $\psi_{\text {leaf }}-\psi_{\mathrm{s}}$.

Measurements of $\psi_{\text {crown }}$ were carried out using a Scholander-type pressure chamber where the whole pot was placed into the chamber and the petiole was cut just above the strawberry crown; the chamber was then pressurized and $\psi_{\text {crown }}$ was determined when the first sap appeared at the cut petiole surface. Four plants per treatment were measured.

COLLECTION OF XYLEM SAP AND DETERMINATION OF $[\mathrm{ABA}]_{\mathrm{xylem}}$. Xylem sap was collected from pressurized roots of potted plants in a Scholander-type pressure chamber following determination of $\psi_{\text {crown }}$. The pressure was increased gradually until 0.3 MPa overpressure was applied (Dodd, 2007) and a 0.5to $1.0-\mathrm{mL}$ aliquot of sap was collected from the cut surface using a pipette; this was transferred into an Eppendorf vial wrapped with aluminum foil. The sap was stored immediately after collection at $-80{ }^{\circ} \mathrm{C}$ for $\mathrm{ABA}$ analysis. The ABA concentration in the xylem sap was analyzed by an enzymelinked immunoabsorbent assay (ELISA) using a monoclonal antibody for ABA, AFRCMAC 252 (Asch, 2000). No crossreaction of antibody with other compounds in xylem sap was detected in the tested interval (Quarrie et al., 1988).

Data ANALysis AND STATISTICs. The observations in Fig. 1 are based on means of the individual observations per treatment per day. The treatment effects of irrigation on soil and plant water characteristics, $g_{\mathrm{s}}$, and $[\mathrm{ABA}]_{\mathrm{xylem}}$ were determined by analysis of variance using the general linear model procedure of SAS (version 9.1; SAS Institute, Cary, NC). Data were subjected to analysis of variance separately for each sampling date, and differences between individual means were determined by $t$ tests, equivalent to Fisher's least significant difference test at $P \leq 0.05$ significance level. The parameters of the nonlinear regression in Figs. 2 and 3 were derived by the nonlinear leastsquares iteration procedure (PROC NLIN), and the parameters in Table 1 and Figs. 2 and 3 were calculated using Eq. 2, where $\mathrm{a}, \mathrm{b}$, and $\mathrm{c}$ are constants.

$$
\text { If } \mathrm{x}>\mathrm{b}, \mathrm{f}(\mathrm{x})=\mathrm{c} \text { and if } \mathrm{x}<\mathrm{b}, \mathrm{f}(\mathrm{x})=\mathrm{ax}+(\mathrm{c}-\mathrm{ab})
$$

The constant a is the slope of the linear part of the regression. In Fig. 2, b is defined as the critical threshold of FTSW and $\mathrm{c}$ is the mean of the estimated parameters before the FTSW drops below the critical threshold. Whereas in Fig. 3, b is defined as the critical threshold of $\psi_{\text {crown }}$ where the $[\mathrm{ABA}]_{\text {xylem }}$ starts to increase and $\mathrm{c}$ is the mean of $[\mathrm{ABA}]_{\mathrm{xylem}}$ before $\psi_{\text {crown }}$ drops below the critical value of $\psi_{\text {crown }}$. The coefficient of determination $\left(\mathrm{r}^{2}\right)$ was 


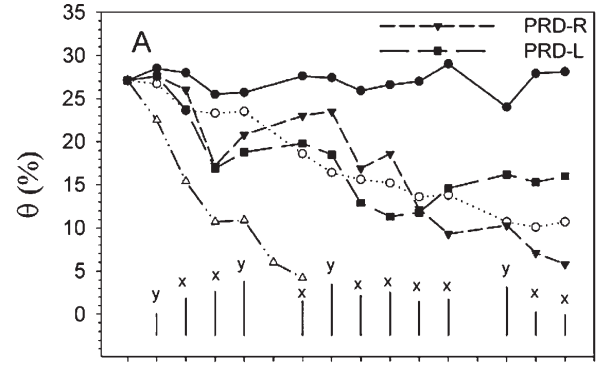

$\begin{array}{llllllllllllll}0 & 1 & 2 & 3 & 4 & 5 & 6 & 7 & 8 & 9 & 10 & 11 & 121314 & 1516\end{array}$
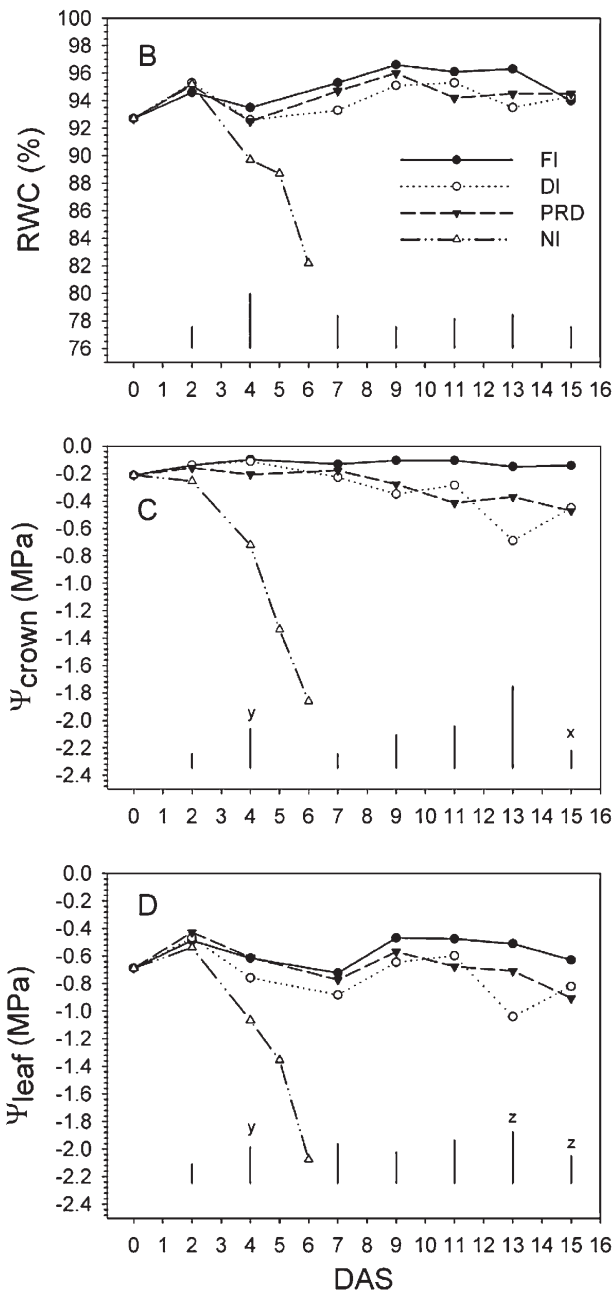
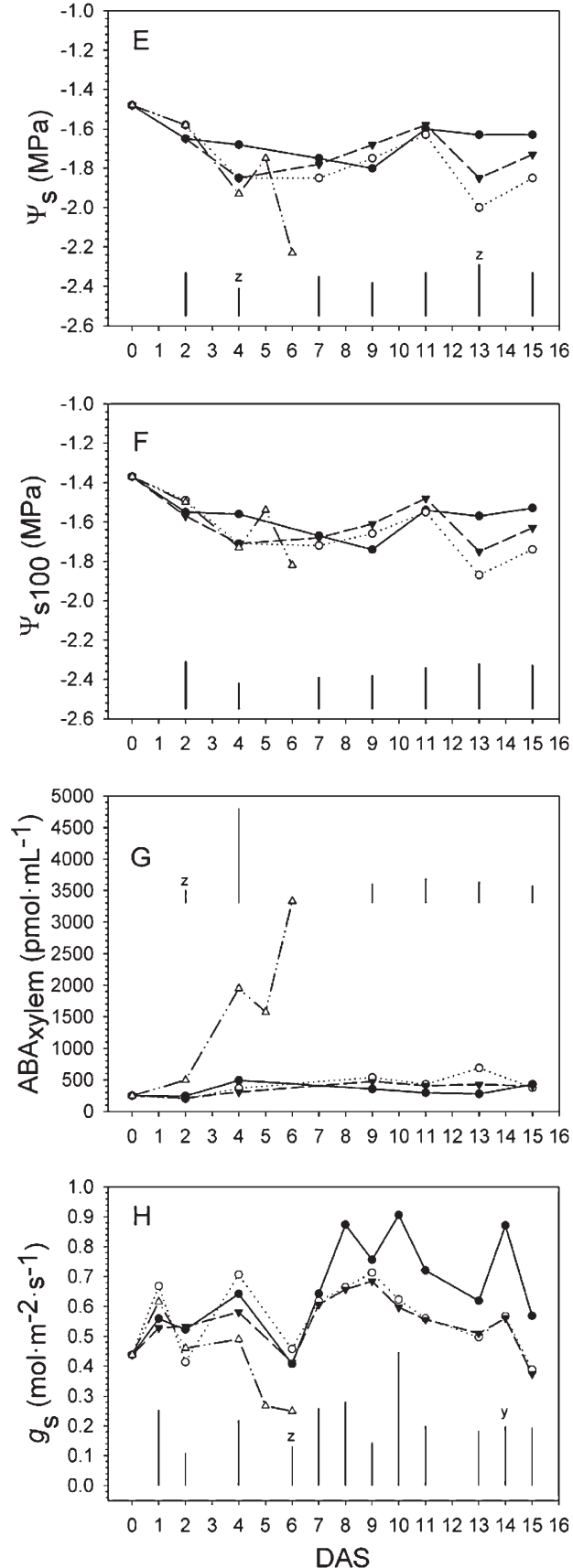

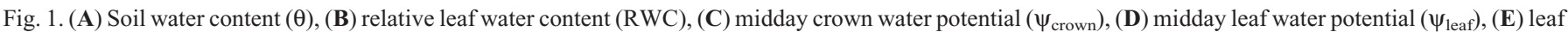
osmotic potential $\left(\psi_{\mathrm{s}}\right),(\mathbf{F})$ leaf $\psi_{\mathrm{s}}$ at full turgor $\left(\psi_{\mathrm{s} 100}\right),(\mathbf{G})$ concentration of abscisic acid in the xylem sap $\left([\mathrm{ABA}]_{\mathrm{xylem}}\right)$, and $(\mathbf{H})$ stomatal conductance $\left(g_{\mathrm{s}}\right)$ of pot-grown strawberry plants during $16 \mathrm{~d}$ after start (DAS) of full irrigation (FI), deficit irrigation (DI), partial root-zone drying (PRD), and nonirrigation (NI) treatments. PRD plants were irrigated on the right $(\mathrm{PRD}-\mathrm{R})$ or the left side $(\mathrm{PRD}-\mathrm{L})$ at each irrigation event. Data points are means per treatment per day $(\mathrm{n}=4)$ and vertical bars are least significant differences (LSD) at $P<0.05 ; \mathrm{z}, \mathrm{y}$, and $\mathrm{x}$ significant at $P<0.05,0.01$, and 0.001, respectively.

calculated as $1-(\mathrm{SSE} / \mathrm{CSS})$, where SSE is the residual sum of squares and CSS is the corrected total sum of squares. The observations in Figs. 3 and 4 are based on means of the individual observations per treatment per day.

\section{Results}

The FI, DI, and PRD treatments lasted for $15 \mathrm{~d}$. The FI plants were, on average, irrigated with $200 \mathrm{~mL}$ of water per plant per day, whereas the DI and PRD plants were, on average, irrigated with $140 \mathrm{~mL}$ of water per plant per day. The NI plants used all plant-available water within the first $6 \mathrm{~d}$.

Soil-Water Relations. The initial $\theta$ values were about $25 \%$ in all treatments (Fig. 1A). The volumetric soil water content remained constant for the FI treatment throughout the experiment. The volumetric soil water content of the DI treatment decreased steadily to about $10 \% 13 \mathrm{~d}$ after start of treatments and it remained at this level until the end of the experiment. The volumetric soil water content of the irrigated and the nonirrigated sides of the PRD treatment dropped rapidly at the 

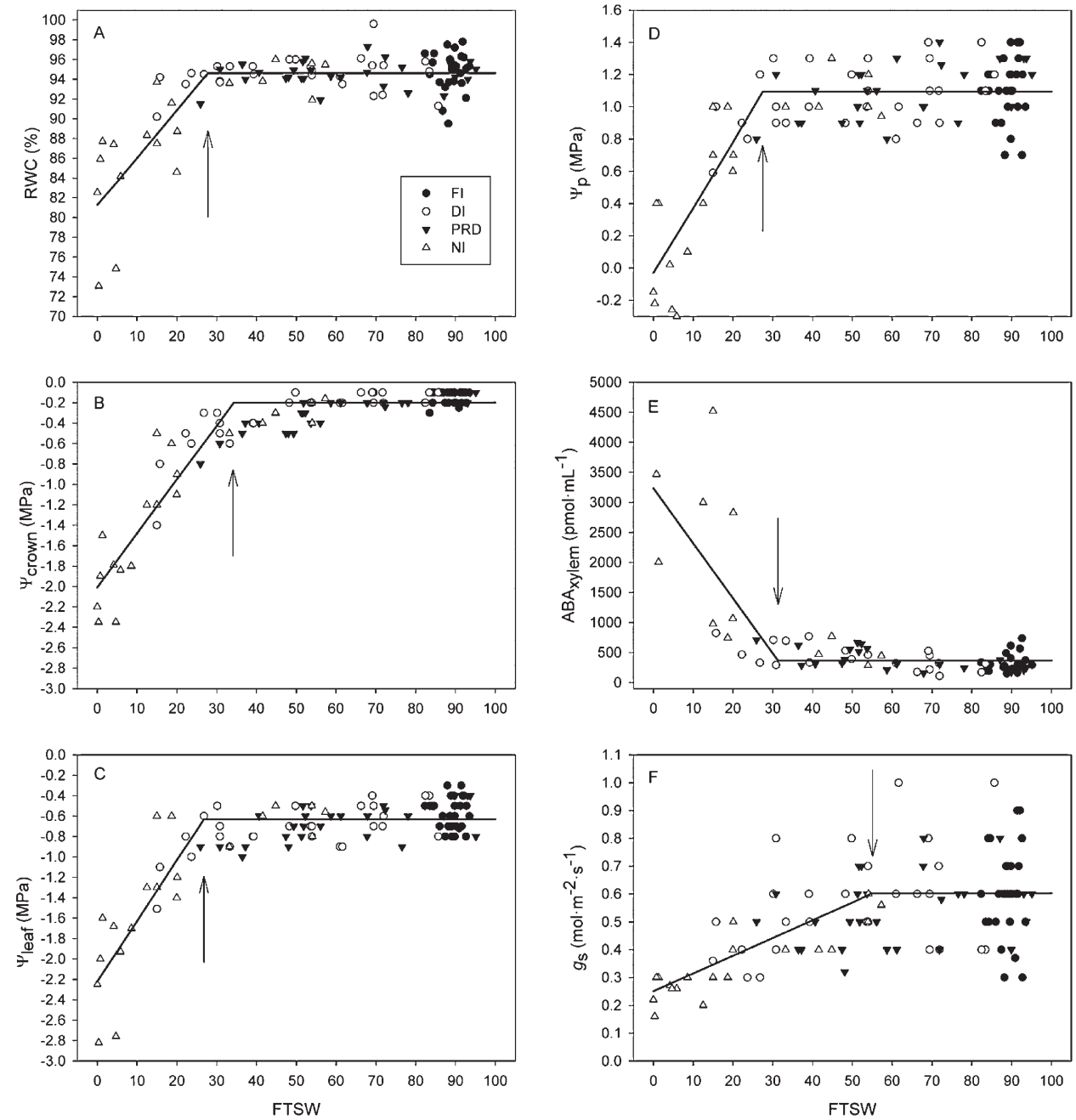

Fig. 2. (A) Relative leaf water content (RWC), (B) midday crown water potential $\left(\psi_{\text {crown }}\right),\left(\right.$ C) midday leaf water potential $\left(\psi_{\text {leaf }}\right),\left(\right.$ D) leaf turgor potential $\left(\psi_{\mathrm{p}}\right),(\mathbf{E})$ concentration of abscisic acid in the xylem sap $\left([\mathrm{ABA}]_{\mathrm{xylem}}\right)$, and $(\mathbf{F})$ stomatal conductance $\left(g_{\mathrm{s}}\right)$ of pot-grown strawberry plants from full irrigation $(\mathrm{FI})$, deficit irrigation (DI), partial root zone drying (PRD), or nonirrigation (NI) treatments as a function of the fraction of transpirable soil water (FTSW). The arrows show the critical threshold of FTSW and the parameters of the nonlinear regression can be seen in Table 1.

beginning of the treatment, and $3 \mathrm{~d}$ after start of treatments, the $\theta$ values on both sides were significant lower than $\theta$ of the DI treatment. Thereafter, $\theta$ of the wet and the dry side of the PRD treatment started to differ from each other, and $5 \mathrm{~d}$ after start of treatments, there was a significant difference in $\theta$ between the two sides. At $10 \mathrm{~d}$ after start of treatments, the irrigation was shifted from PRD-R to PRD-L. The volumetric soil water content of the NI treatment decreased rapidly, and $2 \mathrm{~d}$ after start of treatments, $\theta$ of NI was significantly lower than $\theta$ of the other treatments. By $6 \mathrm{~d}$ after the start of treatments, the reduction of $\theta$ of NI resulted in wilting of the plants and leaf turgor pressure decreased to zero (data not shown).

Plant Physiological Responses. The relative water content was similar in the FI, DI, and PRD plants with a mean of $95 \%$ during the experiment (Fig. 1B). The RWC of the NI plants decreased from $95 \%$ at $2 \mathrm{~d}$ to $82 \%$ at $6 \mathrm{~d}$ after start of treatments.

The $\psi_{\text {crown }}$ of the FI plants was $-0.14 \mathrm{MPa}$ throughout the experiment (Fig. 1C). The $\psi_{\text {crown }}$ of the DI and PRD plants was about $-0.17 \mathrm{MPa}$ until $7 \mathrm{~d}$ after start of treatments, thereafter it decreased linearly to $-0.46 \mathrm{MPa}$ at the end of the experiment.
The $\psi_{\text {crown }}$ of the NI plants decreased from $-0.26 \mathrm{MPa}$ at $2 \mathrm{~d}$ after the start to $-1.86 \mathrm{MPa}$ at $6 \mathrm{~d}$ after the start of treatments.

The $\psi_{\text {leaf }}$ of FI plants was about $-0.58 \mathrm{MPa}$ throughout the experiment (Fig. 1D). The $\psi_{\text {leaf }}$ of the DI and PRD plants decreased slightly, resulting in a significant difference in $\psi_{\text {leaf }}$ compared with FI plants at the end of the experiment. There was no significant difference in $\psi_{\text {leaf }}$ between the DI and PRD plants during the experiment. The $\psi_{\text {leaf }}$ of the NI plants decreased from - $0.54 \mathrm{MPa}$ to $-2.08 \mathrm{MPa}$ at $6 \mathrm{~d}$ after the start of treatments.

The $\psi_{\mathrm{s}}$ was $-1.63,-1.79$, and $-1.73 \mathrm{MPa}$ in the FI, DI, and PRD treated plants, respectively, with an LSD of $0.11 \mathrm{MPa}$ (Fig. $1 \mathrm{E})$. The $\psi_{\mathrm{s}}$ of NI plants was similar to $\psi_{\mathrm{s}}$ of plants from the other treatments, except on the last day when $\psi_{\mathrm{s}}$ decreased to $-2.23 \mathrm{MPa}$ in the NI plants. During most of the experiment, the treatments did not result in osmotic adjustment as $\psi_{\mathrm{s} 100}$ was similar in all the treatments, ranging between -1.5 and -1.9 MPa (Fig. 1F). However at 13 and $15 \mathrm{~d}$ after the start of treatment, the $\psi_{\mathrm{s} 100}$ of DI and PRD plants tended to decrease compared with $\psi_{\mathrm{s} 100}$ of FI (Fig. 1F).

The $[\mathrm{ABA}]_{\mathrm{xylem}}$ was between 200 and $680 \mathrm{pmol} \cdot \mathrm{mL}^{-1}$ in the FI, DI, and PRD plants, with an average value of 


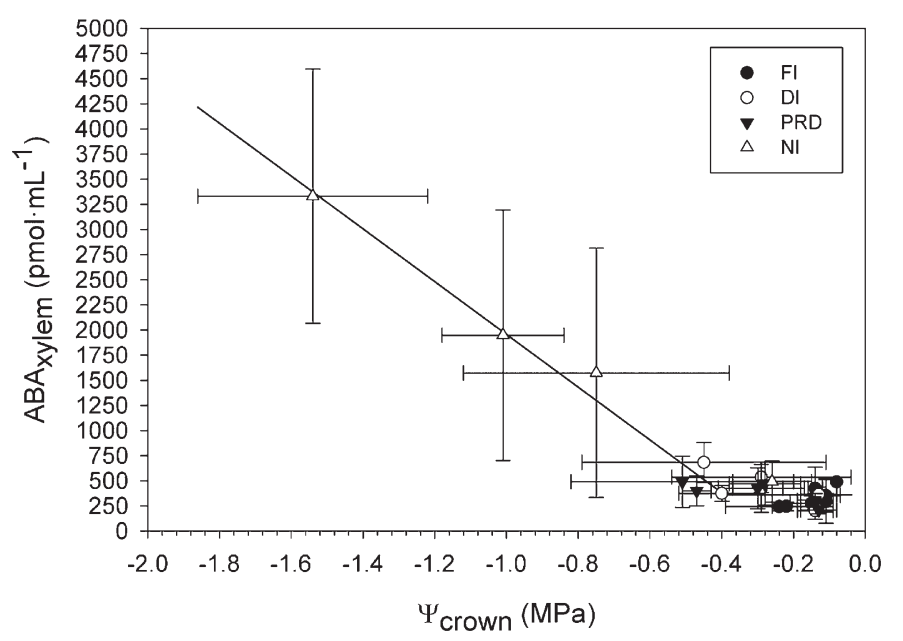

Fig. 3. Relationship between midday crown water potential ( $\left.\psi_{\text {crown }}\right)$ and xylem sap abscisic acid concentration ([ABA $]_{\text {xylem }}$ ) in pot-grown strawberry plants from full irrigation (FI), deficit irrigation (DI), partial root zone drying (PRD), or nonirrigation (NI) treatments. Data points are means per treatment per day $(\mathrm{n}=4)$. Horizontal bars show \pm SD of $\psi_{\text {crown }}$ and vertical bars show \pm SD of $[\mathrm{ABA}]_{\text {xylem}}$.

$370 \mathrm{pmol} \cdot \mathrm{mL}^{-1}$ (Fig. 1G). At $6 \mathrm{~d}$ after the start of treatments, the [ABA $]_{\text {xylem }}$ of NI plants increased to $3300 \mathrm{pmol} \cdot \mathrm{mL}^{-1}$ (Fig. $1 \mathrm{G})$. The $g_{\mathrm{s}}$ of the FI, DI, and PRD plants ranged between 0.4 and $0.9 \mathrm{~mol} \cdot \mathrm{m}^{-2} \cdot \mathrm{s}^{-1}$, with an average of about $0.6 \mathrm{~mol} \cdot \mathrm{m}^{-2} \cdot \mathrm{s}^{-1}$ throughout most of the experiment (Fig. 1H). However, at $7 \mathrm{~d}$ after the start of treatments $g_{\mathrm{s}}$ of DI and PRD plants tended to be consistently lower than the $g_{\mathrm{s}}$ of the FI plants, and at $6 \mathrm{~d}$ after the start of treatments, $g_{\mathrm{s}}$ decreased significantly to 0.25 $\mathrm{mol} \cdot \mathrm{m}^{-2} \cdot \mathrm{s}^{-1}$ in NI plants.

Irrespective of treatment RWC, $\psi_{\text {crown }}, \psi_{\text {leaf }}, \psi_{\mathrm{p}}$, and $g_{\mathrm{s}}$ decreased and $[\mathrm{ABA}]_{\mathrm{xylem}}$ increased when the FTSW fell below a critical relative soil water content (Fig. 2). This critical threshold of FTSW was estimated as the inflexion points where RWC, $\psi_{\text {crown }}, \psi_{\text {leaf }}, \psi_{\mathrm{p}}$, and $g_{\mathrm{s}}$ started to decrease and $[\mathrm{ABA}]_{\mathrm{xylem}}$ started to increase (Fig. 2 and Table 1). The critical threshold of FTSW for $\psi_{\text {crown }}$ was 34\% (Fig. 2B and Table 1), which was higher than the critical threshold of FTSW for RWC, $\psi_{\text {leaf }}$, and $\psi_{\mathrm{p}}$, which ranged from $27 \%$ to $28 \%$ (Fig. 2 , A, C, and D). The critical threshold of FTSW for $[\mathrm{ABA}]_{\mathrm{xylem}}$ was $31 \%$ at $\psi_{\text {soil }}-0.25 \mathrm{MPa}$ (Fig. 2E). $G_{\mathrm{S}}$ was quite variable (Fig. 2F), therefore the critical threshold of FTSW for $\mathrm{g}_{\mathrm{s}}$ could not be accurately estimated (Table 1).

Regression analyses of pooled data from the four irrigation treatments showed a nonlinear relationship between $[\mathrm{ABA}]_{\mathrm{xylem}}$ and $\psi_{\text {crown }}\left(\mathrm{r}^{2}=0.97^{* * *}\right)$ (Fig. 3 and Eq. 2). The critical value of $\psi_{\text {crown }}$ was defined as the point where the $[\mathrm{ABA}]_{\mathrm{xylem}}$ started to increase and this was estimated at $-0.4 \mathrm{MPa}$. By applying a linear correlation analysis between $\psi_{\text {leaf }}$ and $\psi_{\text {crown }}$, the critical value of $\psi_{\text {leaf }}$ was estimated at $-0.8 \mathrm{MPa}$. It was not possible to correlate $g_{\mathrm{s}}$ and $[\mathrm{ABA}]_{\mathrm{xylem}}$ due to a lack of variance homogeneity (Fig. 4A). The $g_{\mathrm{s}}$ showed a high variation at low values of $[\mathrm{ABA}]_{\mathrm{xylem}}$ and $g_{\mathrm{s}}$ was highly affected by the water vapor pressure deficit of the air. However, within small intervals of VPD, $g_{\mathrm{s}}$ tended to decrease as a function of $[\mathrm{ABA}]_{\text {xylem }}$ (Fig. 4B).

\section{Discussion}

Soll-water Relations. The DI and PRD treatments resulted in a significant reduction in $\theta$ compared with the FI treatment (Fig. 1A). However, significant differences were only observed between $\theta$ of the DI and PRD treatments on a few occasions, which is possibly one of the main reasons why we did not determine any differences in plant water responses between the DI and PRD treatments. If the experiment had run for a longer time period, the DI and PRD treatment may have resulted in more consistent difference in relation to the plant water responses. In the PRD treatment, it was not possible to keep the wet root zone close to $100 \%$ of pot-holding capacity with an irrigation of $70 \%$ of the FI irrigation volume, and the $\theta$ of the dry root zone was significantly higher than $\theta$ of the NI treatment. These findings may be due to the existence of a "hydraulic lift" causing water movement from moist to dry soil layers through the plant root system (Caldwell et al., 1998; Stoll et al., 2000). Also, the root water uptake is probably increased in the irrigated soil compartment and reduced in the drying soil as water uptake is dependent on water potential gradients and resistances in the soil-plant system (Jensen et al., 1993; Kang et al., 2003).

Plant Physiological resPonses. The plant physiological parameters between FI plants and DI and PRD plants were not consistently different, whereas in NI plants, most of the physiological parameters were affected (Fig. 1). We determined the same leaf water relations, $g_{s}$, and $[\mathrm{ABA}]_{\mathrm{xylem}}$ responses to reduced water supply irrespective of if it was applied to the

Table 1. Nonlinear regression parameters for the relationships between the fraction of transpirable soil water (FTSW) and stomatal conductance $\left(g_{\mathrm{s}}\right)$, midday crown water potential $\left(\psi_{\text {crown }}\right)$, concentration of abscisic acid in the xylem sap ([ABA $\left.]_{\text {xylem }}\right)$, relative water content of the leaf $(\mathrm{RWC})$, midday leaf water potential $\left(\psi_{\text {leaf }}\right)$, and leaf turgor potential $\left(\psi_{\mathrm{p}}\right)$ of leaves from pot-grown strawberry plants under full irrigation (FI), deficit irrigation (DI), partial root zone drying (PRD), and nonirrigation (NI).

\begin{tabular}{|c|c|c|c|c|c|c|c|c|}
\hline & $a^{z}$ & $95 \%$ CI for $\mathrm{a}^{\mathrm{y}}$ & $\mathrm{b}^{\mathrm{z}}$ & $95 \%$ CI for $b^{y}$ & $\mathrm{r}^{2 \mathrm{x}}$ & $\mathrm{N}^{\mathrm{w}}$ & $\mathrm{c}^{\mathrm{z}}$ & $95 \%$ CI for $\mathrm{c}^{\mathrm{y}}$ \\
\hline$g_{\mathrm{s}}$ & $0.006^{* * *}$ & $0.004-0.009$ & 55 & $43-66$ & 0.40 & 103 & 0.60 & $0.57-0.64$ \\
\hline$\psi_{\text {crown }}$ & $0.05 * * *$ & $0.05-0.06$ & 34 & $32-37$ & 0.89 & 104 & -0.20 & $-0.24-(-0.16)$ \\
\hline$[\mathrm{ABA}]_{\text {xylem }}$ & $-92 * * *$ & $-120-(-63)$ & 31 & $26-36$ & 0.61 & 74 & 365 & 242-488 \\
\hline$\psi_{\text {leaf }}$ & $0.06 * * *$ & $0.05-0.07$ & 27 & $23-30$ & 0.77 & 104 & -0.63 & $-0.68-(-0.58)$ \\
\hline$\psi_{\mathrm{p}}$ & $0.04 * * *$ & $0.03-0.05$ & 27 & $23-32$ & 0.70 & 100 & 1.09 & 1.05-1.13 \\
\hline
\end{tabular}

${ }^{\mathrm{z}}$ If FTSW $>$ b, f(FTSW) $=\mathrm{c}$, and if FTSW $<\mathrm{b}$, then $\mathrm{f}($ FTSW $)=\mathrm{a} \times($ FTSW $)+[\mathrm{c}-(\mathrm{a} \times \mathrm{b})]$.

${ }^{\mathrm{y}} 95 \%$ confidence interval of parameters $\mathrm{a}, \mathrm{b}$, or $\mathrm{c}$.

${ }^{\mathrm{x}}$ Coefficient of determination.

wNumber of observations.

$* * *$ Significant at $P \leq 0.001$. 

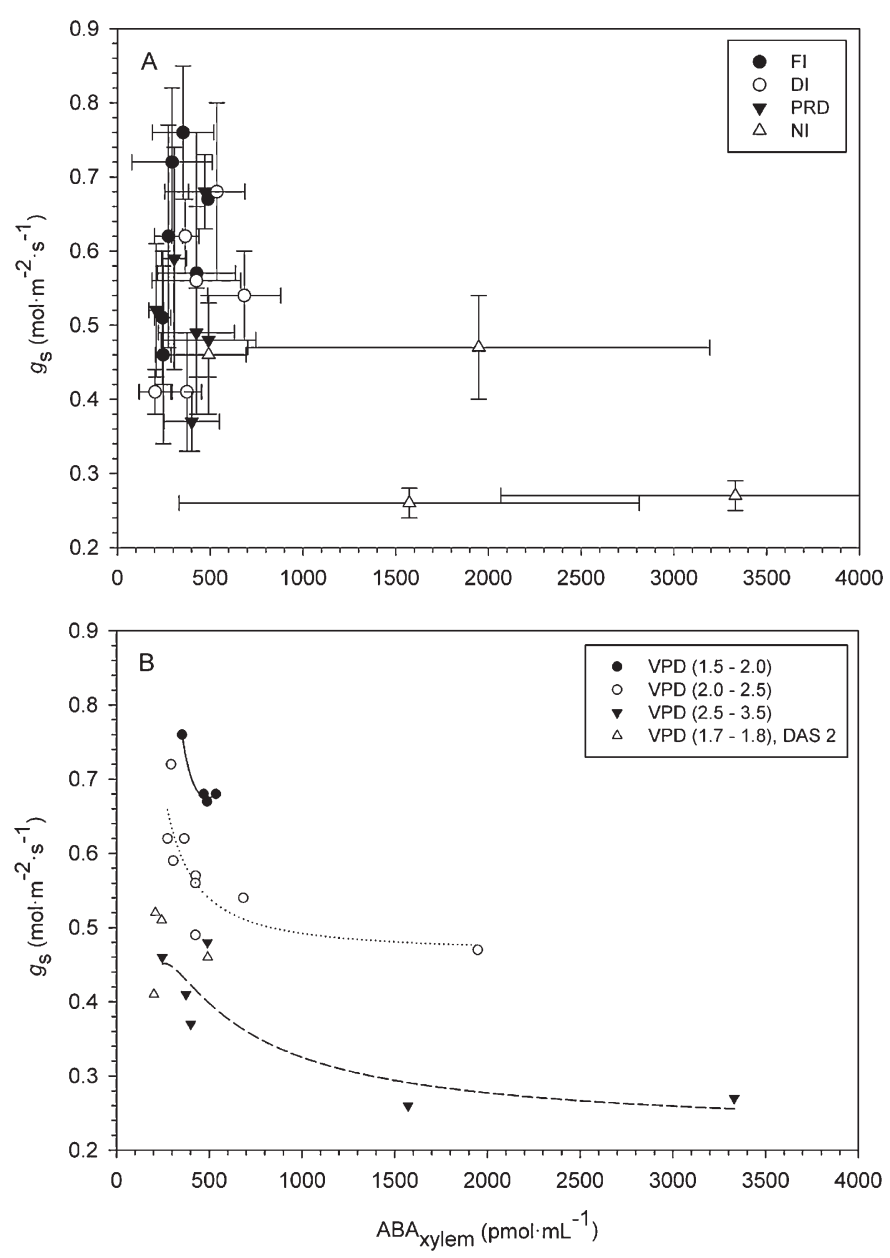

Fig. 4. Relationship between stomatal conductance $\left(g_{\mathrm{s}}\right)$ and concentration of abscisic acid in the xylem sap ([ABA $]_{\text {xylem }}$ ) of pot-grown strawberry plants (A) from full irrigation (FI), deficit irrigation (DI), partial root zone drying (PRD), or nonirrigation (NI) treatments. Horizontal bars show $\pm \mathrm{SD}$ of $[\mathrm{ABA}]_{\mathrm{xylem}}$ and vertical bars show \pm SD of $g_{\mathrm{s}}$. Relationship between $g_{\mathrm{s}}$ and $[\mathrm{ABA}]_{\text {xylem }}$ of pot-grown strawberry plants $(\mathbf{B})$ at different ranges of water vapor pressure deficits (VPD). Data points are means per treatment per day $(n=4)$, where DAS represents d after start of irrigation treatment.

whole or to half of the root zone. This is in contrast to some previous studies on other crops, where PRD plants were less affected by water savings in comparison with DI plants (Davies and Hartung, 2004; Kirda et al., 2004). However, Sadras (2009) determined by a meta-analysis, where pairwise comparison of DI and PRD was applied, that in $80 \%$ of the analyzed cases, the PRD irrigation resulted in $\pm 20 \%$ range difference in yield per unit irrigation compared with DI where in only $20 \%$ of the cases, PRD outperformed DI by $20 \%$ or more.

The RWC of water-stressed strawberry plants has been shown to depend on species. Zhang and Archbold (1993a) found that Fragaria virginiana plants wilted at a RWC of $82 \%$ and were more sensitive to water deficit stress than Fragaria chiloensis plants, which wilted at a RWC of $60 \%$. In the present study RWC of the FI, DI, and PRD plants was 95\% throughout the experiment (Fig. 1A), where the NI plants wilted within $6 \mathrm{~d}$ at a RWC of $82 \%$. This is within the range of RWC during periods of soil drying reported in other studies of Fragaria species (Zhang and Archbold, 1993a, 1993b). The $\psi_{\text {s100 values obtained }}$ in the present study varied between -1.3 and $-1.9 \mathrm{MPa}$ (Fig. 1F), which is similar to values reported for strawberries (Save et al., 1993; Zhang and Archbold, 1993b), but low relative to other dicot species, such as lupin [Lupinus angustifolius (Jensen et al., 1998)] and rape [Brassica napus (Jensen et al., 1996)]. The DI and PRD treatments resulted in a minor osmotic adjustment from 13 to $15 \mathrm{~d}$ after start of treatments (Fig. $1 \mathrm{~F}$ ) when $\psi_{\text {s } 100}$ was 0.1 to $0.2 \mathrm{MPa}$ lower than $\psi_{\mathrm{s} 100}$ of the FI-treated plants. Although the potential for osmotic adjustment in strawberries seems limited (Renquist et al., 1982; Save et al., 1993), a low $\psi_{\mathrm{s}}$ maintained turgor and water uptake during soil drying (Jensen et al., 1993). A greater ability to adjust osmotically has been found in native strawberry species (Zhang and Archbold, 1993a), which provides a potential source of plant material for breeding programs to increase drought tolerance in strawberry.

From 7 to $15 \mathrm{~d}$ after the start of treatments, DI and PRD treatments showed a slight decrease in $\psi_{\text {crown }}$ and $\psi_{\text {leaf }}$ compared with the FI treatment (Fig. 1C). A similar decrease in $\psi_{\text {crown }}$ and $\psi_{\text {leaf }}$ of the DI and PRD plants indicated that these plants experienced similar levels of water deficit despite the different irrigation strategies. This result is somewhat different from the expectation that plant water status would be less affected by PRD than DI, as reported in other crops (Davies and Hartung, 2004). The similar level of water deficit in DI and PRD plants is supported by the similarity in $\theta$ (Fig. 1A), water use (data not shown), and $g_{\mathrm{s}}$ (Fig. $1 \mathrm{H}$ ) in the two irrigation treatments. These results confirmed those reported for fieldgrown strawberry where Liu et al. (2007) determined similar $\psi_{\text {leaf }}$ in the DI and PRD plants irrigated with $60 \%$ of the irrigation volume of the FI plants. Both of these studies disagree with the earlier hypotheses that PRD would maintain shoot water status better than DI (Davies and Hartung, 2004). Our study suggests that in the PRD treatment, the soil water availability in the dry side of the root system was not reduced to a level where increased $[\mathrm{ABA}]_{\mathrm{xylem}}$ was induced. The $[\mathrm{ABA}]_{\text {xylem }}$ only increased significantly when the FTSW dropped below $31 \%$ (Fig. 2E and Table 1) and the $\psi_{\text {soil }}$ dropped below $-0.25 \mathrm{MPa}$; it was not until 11 to $13 \mathrm{~d}$ after start of treatments that the $\psi_{\text {soil }}$ of DI and PRD dropped below this critical value. It should also be considered that there could have been a limited export of ABA from the roots to the shoots, as the sap flow from roots grown in drying soil has been shown to decrease (Dodd et al., 2008; Liu et al., 2008).

In the present study, $[\mathrm{ABA}]_{\text {xylem }}$ of strawberry plants increased significantly as the soil dried, a result consistent with findings in other crops; e.g., soybean (Glycine max) (Liu et al., $2005 \mathrm{a})$. The $[\mathrm{ABA}]_{\text {xylem }}$ was linearly correlated with the $\psi_{\text {crown }}$ below the critical value of $-0.4 \mathrm{MPa}$ (Fig. 3), suggesting that strawberry plants are able to sense soil water availability and that increasing water deficiency stimulated formation of ABA in the roots after the critical threshold of $\psi_{\text {soil }}$ at $-0.25 \mathrm{MPa}$ had been reached. At a $\psi_{\text {crown }}$ of $-1.0 \mathrm{MPa}$ the $[\mathrm{ABA}]_{\mathrm{xylem}}$ was about 2000 pmol. $\mathrm{mL}^{-1}$ (Fig. 3), which is in agreement with $[\mathrm{ABA}]_{\mathrm{xylem}}$ found in potato at a similar level of $\psi_{\text {crown }}$ (Liu et al., 2005b). The correlation between $\psi_{\text {crown }}$ and $\psi_{\text {leaf }}$ demonstrated that $\psi_{\text {leaf }}$ had to decrease below $-0.8 \mathrm{MPa}$ before an increase in $[\mathrm{ABA}]_{\mathrm{xylem}}$ could be expected. Sruamsiri and Lenz (1986) also reported photosynthesis and transpiration in strawberry plants only dropped when $\psi_{\text {leaf }}$ fell below a threshold value of $-1.0 \mathrm{MPa}$.

It was not possible to derive a correlation between $g_{\mathrm{s}}$ and $[\mathrm{ABA}]_{\mathrm{xylem}}$ due to a lack in variance homogeneity (Fig. 4A) as a result of large variation in $g_{\mathrm{s}}$ at low values of $[\mathrm{ABA}]_{\mathrm{xylem}}$. Stomatal conductance was influenced by VPD, whereas the 
response of $g_{\mathrm{s}}$ to $[\mathrm{ABA}]_{\mathrm{xylem}}$ was relatively small; these results are similar to those reported by Tardieu et al. (1993). However, the differences in VPD and $[\mathrm{ABA}]_{\mathrm{xylem}}$ cannot explain all the variation in $g_{\mathrm{s}}$, as $g_{\mathrm{s}} 2 \mathrm{~d}$ after the start of treatments were relatively low despite relatively low VPD of 1.7 to $1.8 \mathrm{kPa}$ (Fig. 4B), indicating that other factors such as temperature (Johnson and Ferrell, 1983) and radiation (Sruamsiri and Lenz, 1985) must have also influenced $g_{\mathrm{s}}$. Thus, $g_{\mathrm{s}}$ of strawberry appears to be less sensitive to root originated ABA under conditions of soil drying than in other crops, e.g., potatoes (Liu et al., 2008). Water status in strawberry is to a great extent controlled by hydraulic signals (level of soil drying) than by $[\mathrm{ABA}]_{\mathrm{xylem}}$. This implies that in a short-term production system, DI and PRD irrigation strategies may be applied to strawberry plant with the same result in relation to plant-water relations and $[\mathrm{ABA}]_{\mathrm{xylem}}$. Therefore, PRD irrigation strategies cannot be economically justified in commercial strawberry production when considering the cost and management complexity of implementing the PRD system on a large scale.

\section{Literature Cited}

Asch, F. 2000. Determination of abscisic acid by indirect enzyme-linked immunoabsorbent assay (ELISA). Tech. Rpt., Lab. Agrohydrology and Bioclimatology. Dept. Agr. Sci., The Royal Veterinary and Agricultural University, Taastrup, Denmark.

Barrs, H.D. and P.E. Weatherley. 1962. A re-examination of relative turgidity technique for estimating water deficits in leaves. Aust. J. Biol. Sci. 15:413-428.

Caldwell, M.M., T.E. Dawson, and J.H. Richards. 1998. Hydraulic lift: Consequences of water efflux from the roots of plants. Oecologia 113:151-161.

Davies, W.J. and W. Hartung. 2004. Has extrapolation from biochemistry to crop functioning worked to sustain plant production under water scarcity? Proc. Fourth Intl. Crop Sci. Congr. p. 1-14.

Dodd, I.C. 2007. Soil moisture heterogeneity during deficit irrigation alters root-to-shoot signaling of abscisic acid. Funct. Plant Biol. 34:439-448.

Dodd, I.C., G. Egea, and W.J. Davies. 2008. Accounting for sap flow from different parts of the root system improves the prediction of xylem ABA concentration in plants grown with heterogeneous soil moisture. J. Expt. Bot. 59:4083-4093.

Dry, P.R. and B.R. Loveys. 1999. Grapevine shoot growth and stomatal conductance are reduced when part of the root system is dried. Vitis 38:151-156.

Guang-Cheng, S., Z. Zhan-Yu, L. Na, Y. Shuang-En, and X. WengGang. 2008. Comparative effects of deficit irrigation (DI) and partial root zone drying (PRD) on soil water distribution, water use, growth and yield in greenhouse grown hot pepper. Scientia Hort. 119:11-16.

Hoppula, K.I. and T.J. Salo. 2007. Tensiometer-based irrigation scheduling in perennial strawberry cultivation. Irrig. Sci. 25:401-409.

Jensen, C.R., H. Svendsen, M.N. Andersen, and R. Losch. 1993. Use of the root contact concept, an empirical leaf conductance model and pressure-volume curves in simulating crop water relations. Plant Soil 149:1-26.

Jensen, C.R., V.O. Morgensen, G. Mortensen, M.N. Andersen, J.K. Schjoerring, J.H. Thage, and J. Koribidis. 1996. Leaf photosynthesis and drought adaptation in field-grown oilseed rape (Brassica napus L.). Aust. J. Plant Physiol. 23:631-644.

Jensen, C.R., V.O. Mogensen, H.-H. Poulsen, I.E. Henson, S. Aagot, E. Hansen, M. Ali, and B. Wollenweber. 1998. Soil water matric potential rather than water content determines drought responses in field-grown lupin (Lupinus angustifolius L.). Aust. J. Plant Physiol. $25: 353-363$.
Johnson, J.D. and W.K. Ferrell. 1983. Stomatal response to vapour pressure deficit and the effect of plant water stress. Plant Cell Environ. 6:451-456.

Kang, S.Z., X. Hu, P. Jerie, and J.H. Zhang. 2003. The effects of partial root zone drying on root, trunk sap flow and water balance in an irrigated pear (Pyrus communis L.) orchard. J. Hydrol. (Amst.) 280: 192-206.

Kirda, C., M. Cetin, Y. Dasgan, S. Topcu, H. Kaman, B. Ekici, M.R. Derici, and A.I. Ozguven. 2004. Yield response of greenhouse grown tomato to partial root drying and conventional deficit irrigation. Agr. Water Mgt. 69:191-201.

Liu, F., M.N. Andersen, S.E. Jacobsen, and C.R. Jensen. 2005a. Stomatal control and water use efficiency of soybean (Glycine max L. Merr.) during progressive soil drying. Environ. Exp. Bot. 54:33-40. Liu, F., C.R. Jensen, A. Shahanzari, M.N. Andersen, and S.E. Jacobsen. 2005b. ABA regulated stomatal control and photosynthetic water use efficiency of potato (Solanum tuberosum L.) during progressive soil drying. Plant Sci. 168:831-836.

Liu, F., R. Song, X. Zhang, A. Shahnazari, M.N. Andersen, F. Plauborg, S.-E. Jacobsen, and C.R. Jensen. 2008. Measurement and modeling of ABA signaling in potato (Solanum tuberosum L.) during partial root-zone drying. Environ. Exp. Bot. 63:385-391.

Liu, F., S. Savic, C.R. Jensen, A. Shahnazari, S.E. Jacobsen, R. Stikic, and M.N. Andersen. 2007. Water relations and yield of lysimetergrown strawberries under limited irrigation. Scientia Hort. 111:128132.

Madsen, H.B., C.R. Jensen, and T. Boysen. 1986. A comparison of the thermocouple psychrometer and the pressure plate methods for determination of soil water characteristic curves. Eur. J. Soil Sci. 37:357-362.

Quarrie, S.A., P.N. Whitford, N.E.J. Appleford, T.L. Wang, S.K. Cook, I.E. Henson, and B.R. Loveys. 1988. A monoclonal antibody to $(\mathrm{S})$-abscisic acid: Its characterisation and use in a radioimmunoassay for measuring abscisic acid in crude extracts of cereal and lupin leaves. Planta 173:330-339.

Renquist, A.R., P.J. Breen, and L.W. Martin. 1982. Influences of water status and temperature on leaf elongation in strawberry. Scientia Hort. 18:77-85.

Sadras, V.O. 2009. Does partial root-zone drying improve irrigation water productivity in the field? A meta-analysis. Irrig. Sci. 27:183190.

Save, R., J. Penuelas, O. Marfa, and L. Serrano. 1993. Changes in leaf osmotic and elastic properties and canopy structure of strawberries under mild water-stress. HortScience 28:925-927.

Shahnazari, A., F. Liu, M.N. Andersen, S.E. Jacobsen, and C.R. Jensen. 2007. Effects of partial root-zone drying on yield, tuber size and water use efficiency in potato under field conditions. Field Crops Res. 100:117-124.

Sruamsiri, P. and F. Lenz. 1985. Photosynthesis and stomatal behaviour of strawberries. I. Effect of light. Gartenbauwissenschaft 50:78-83.

Sruamsiri, P. and F. Lenz. 1986. Photosynthesis and stomatal behaviour of strawberries (Fragaria $\times$ ananassa Duch.). VI. Influence of water deficiency. Gartenbauwissenschaft 51:84-92.

Stoll, M., B. Loveys, and P. Dry. 2000. Hormonal changes induced by partial root zone drying of irrigated grapevine. J. Expt. Bot. 51:16271634.

Tardieu, F., J. Zhang, and D.J.G. Gowing. 1993. Stomatal control by both ABA in the xylem sap and leaf water status: A test of a model for droughted or ABA-fed field-grown maize. Plant Cell Environ. 16:413-420.

Zhang, B. and D.D. Archbold. 1993a. Water relations of a Fragaria chiloensis and a $F$. virginiana selection during and after water deficit stress. J. Amer. Soc. Hort. Sci. 118:274-279.

Zhang, B. and D.D. Archbold. 1993b. Solute accumulation in leaves of a Fragaria chiloensis and a $F$. viginiana selection responds to water deficit stress. J. Amer. Soc. Hort. Sci. 118:280-285. 